\title{
Antidiabetic and antioxidant potentials of Vitellaria paradoxa barks in alloxan-induced diabetic rats
}

\author{
David Miaffo ${ }^{1 *}$, Oulianovie Guessom Kamgue², Narcisse Ledang Tebou', Clarice Maa Maa Temhoul ${ }^{1}$ and \\ Albert Kamanyi ${ }^{2}$
}

\begin{abstract}
Background: Vitellaria paradoxa ( $V$. paradoxa) is a plant used in traditional medicine in the treatment of many diseases including diabetes mellitus. Although the different parts of this plant are used empirically as antidiabetic drug, no scientific work to our knowledge has yet been undertaken to evaluate its effects on blood glucose, and lipid and antioxidant parameters of diabetic animals. The objective of this study is therefore to evaluate the hypoglycaemic, hypolipidemic and antioxidant activities of the aqueous extract of $V$. paradoxa barks in diabetic rats.

Methods: Diabetes was induced by intraperitoneal injection of alloxan $(120 \mathrm{mg} / \mathrm{kg} \mathrm{bw})$. Thirty male albino rats were divided into groups and orally treated for 14 days with distilled water, glibenclamide ( $2.5 \mathrm{mg} / \mathrm{kg} \mathrm{bw}$ ) and aqueous extract of V. paradoxa (125, 250 and $500 \mathrm{mg} / \mathrm{kg} \mathrm{bw})$. Glycaemia, insulin level, relative body weight, hepatic glycogen level, some liver enzymes, and lipid and antioxidant parameters were evaluated.

Results: The results showed that the extract caused a significant increase in relative body weight, insulin level, HDLcholesterol, hepatic glycogen rate, and fructose-1,6-biphosphate and glucokinase activities. A significant decrease in glycaemia, glucose-6-phosphatase activity, total cholesterol, triglycerides and LDL-cholesterol were also observed after the administration of $V$. paradoxa. Glutathione level and the activities of catalase and superoxide dismutase increased significantly while the nitric oxide and malondialdehyde levels decreased significantly in the liver of animals treated with the extract of $V$. paradoxa.
\end{abstract}

Conclusion: These results justify the hypoglycaemic, hypolipidemic and antioxidant effects of aqueous extract of $V$. paradoxa barks, which can reduce the complications associated with diabetes.

Keywords: Vitellaria paradoxa, Insulin, Hypoglycaemia, Antioxidant, Lipid parameters, Aqueous extract

\section{Introduction}

Diabetes mellitus is a chronic metabolic disease that occurs when fasting glycaemia greater than or equal to $126 \mathrm{mg} / \mathrm{mL}$ [1]. Hyperglycemia can result in either pancreatic dysfunction, characterized by its inability to produce enough insulin responsible for the breakdown of sugar in the body, or defects in cellular glucose uptake. The incidence of diabetes has increased dramatically in recent years worldwide [2]. In fact, the number of patients was estimated at about 422 million in 2014 and is

\footnotetext{
* Correspondence: david_miaffo@yahoo.fr

'Department of Life and Earth Sciences, Higher Teachers' Training College,

University of Maroua, Maroua, Cameroon

Full list of author information is available at the end of the article
}

expected to exceed 642 million in 2040 [3]. Diabetes deaths were 1.5 million in 2012 and will reach 3.7 million in 2040 worldwide [4]. The African continent with 32.8 million patients in 2014 will see this number increase to 41.4 million in 2035 [3].

Diabetes is associated to oxidative stress (OS) that disrupts the insulin secretion and promotes insulin resistance and cardiovascular complications associated with it. This OS is due to a rupture in the physiological balance that exists in the organism between the oxidizing molecules and the antioxidant defense systems. In addition to the antioxidant defenses found in the body, the diet provides many antioxidants including vitamins and trace elements [5]. However, products with 
antidiabetic and antioxidant effects would be very effective in treating diabetic patients.

The conventional treatment of diabetes that involves daily injections of insulin requires a large financial means. Moreover, the choice of oral antidiabetic drugs (ADO) depends on the patient's profile, lifestyle, level of glycemic control, access to medication, economic status. Due to these many limitations, most people resort to herbal medicine because plants with antidiabetic properties are available, less expensive and have few adverse side effects [6]. In addition, according to the World Health Organization (WHO), the investigation of hypoglycemic agents of medicinal plants has become more significant [7]. Most herbal medicines contain classes of chemical compounds such as glycosides, alkaloids, terpenoids, flavonoids, carotenoids, phenols that have a significant hypoglycemic effect [8].

In this study, we focused our interest on $V$. paradoxa, a plant used in traditional African medicine to treat hemorrhoids, constipation, dysentery, malaria, tooth decay and diabetes. Previous work carried out on this plant has shown that the methanolic extract of its fruits inhibits lipid peroxidation in vitro [9]. In addition, the hydro ethanolic extract of the barks of $V$. paradoxa has antihyperglymic properties when administered orally in rabbits [10]. However, no previous antidiabetic and antioxidant studies were performed on the aqueous extract of $V$. paradoxa barks. The objective of this study was to evaluate the hypoglycaemic, hypolipidemic and antioxidant properties of the aqueous extract of the barks of $V$. paradoxa in alloxan-induced diabetic rats.

\section{Materials and methods}

\section{Chemicals and drugs}

Sodium chloride, disodium phosphate, D-glucose, trisodium citrate, dithiobisnitrobenzoate, potassium dihydrogenphosphate, sodium hydrogenphosphate, potassium dichromate and naphthylethylene diamine were purchased from Edu-Lab Biology Kit (Bexwell, Norfolk PE38 9GA, UK). Alloxan, orthophosphoric acid, thiobarbituric acid, trichloroacetic acid, adrenaline, trichloroacetic acid and kits for biochemical assays were purchased from SigmaAldrich, Saint. Louis, USA. Glibenclamide, ketamine, diazepam, dexamethasome were purchased from a local pharmacy store.

\section{Plant material}

The plant material consisted of barks of $V$. paradoxa, harvested in 2018 in Ngong (Cameroon) and authenticated at the Cameroon Herbarium in number 47670 HNC. The harvested barks were washed with tap water and air dried in the shade. Then, they were crushed using a grinder until obtaining a powder.

\section{Preparation of the plant extract}

Two hundred grams $(200 \mathrm{~g})$ of powder of $V$. paradoxa barks were introduced into $1750 \mathrm{~mL}$ of distilled water and the mixture was boiled for $30 \mathrm{~min}$. After cooling, the solution was filtered with a filter paper No1. The filtrate obtained was evaporated in the oven at $45^{\circ} \mathrm{C}$, which allowed us to obtain $33.66 \mathrm{~g}$ of crude extract, a yield of $16.83 \%$. The crude extract of the barks of $V$. paradoxa was dissolved in distilled water to obtain the various doses of extract.

\section{Animal material}

Male albino Wistar rats aged 10 to 12 weeks and weighing between $220 \mathrm{~g}$ and $280 \mathrm{~g}$ were used in the experiment. They were purchased form the animal house of the Department of Animal Biology, University of Dschang, Cameroon, raised in the polystyrene cages and maintained under room temperature, relative humidity and a normal day/night cycle. They received drinking water at will and standard diet ad libitum. All animal procedures were conducted with strict adherence to the NIH Guide for the care and use of Laboratory animals (NIH Publication 85-23 Rev. 1985).

\section{Induction of diabetes}

Animals were fasted for $12 \mathrm{~h}$ and received an intraperitoneal injection (i.p) of the alloxan solution $(150 \mathrm{mg} / \mathrm{kg})$ in freshly prepared saline. The animals were allowed to drink $5 \%$ glucose solution overnight to prevent hypoglycaemia. Seventy-two hours later, their blood glucose was taken at the tail vein using test strips and glucometer (One Touch Ultra Easy). Rats with fasting glucose greater than or equal to $126 \mathrm{mg} / \mathrm{dL}$ were considered diabetic and used for the experiment.

\section{Distribution and treatment of animals}

Thirty (30) rats were randomly divided into six groups of five rats each. These rats received the various gavage treatments for 14 days as follows:

- Group 1 (normal control) received $10 \mathrm{~mL} / \mathrm{kg}$ bw of distilled water;

- Group 2 (diabetic control) received $10 \mathrm{~mL} / \mathrm{kg}$ bw of distilled water;

- Group 3 (positive control) received $2.5 \mathrm{mg} / \mathrm{kg}$ bw of the glibenclamide;

- Groups 4, 5 and 6 received the extract at the respective doses of 125,250 and $500 \mathrm{mg} / \mathrm{kg}$ bw.

The body weight of the animals was evaluated on the 1st, 7th and 14th days of the experiment. 


\section{Collection of blood and organs}

At the end of the experiment, the animals were fasted for $12 \mathrm{~h}$ and then anesthetized with an intraperitoneal injection of the ketamine/diazepam association $(50 \mathrm{mg}$ / $\mathrm{kg}$ bw, i.p/10 mg/kg bw, i.p). The abdominal cavity was opened and the blood taken by catheterization of the abdominal artery, put into the tubes without anticoagulant, left to rest for $1 \mathrm{~h}$ and centrifuged at $3000 \mathrm{rmp} / \mathrm{min}$ for $15 \mathrm{~min}$. The serum obtained was stored at $-20^{\circ} \mathrm{C}$ for assays of the lipid parameters.

Immediately after blood collection, the liver was removed, stripped of fat tissue, cleaned in $\mathrm{NaCl} 0.9 \%$ and wrung out. A portion of this organ was fragmented and turned into a homogenous solution. The different homogenates were centrifuged at $2500 \mathrm{rpm} / \mathrm{min}$ for $15 \mathrm{~min}$. The supernatants obtained were stored at $-20{ }^{\circ} \mathrm{C}$ for the determination of the antioxidant parameters, the glycogen content and the activity of certain liver enzymes.

\section{Evaluation of biochemical parameters}

Fasting blood glucose levels of the animals were evaluated on days 1, 7 and 14 of the experiment. Plasma insulin by enzyme linked immunosorbent assay (ELISA) kit was measured on day 14. Glycogen content of liver was measured according to Van method [11]. Glucokinase was assayed according to the method of Brandstrup et al. [12]. Glucose-6-phosphatase was assayed according to the method of Koida and Oda [13]. Fructose-1,6bisphosphatase was assayed by the methods of Gancedo and Gancedo [14].

Total cholesterol assay was performed following a colorimetric enzymatic method described by Trinder using Dialab kit [15]. The HDL-c assay was described by Wiebe et al. [16] using Inmesco kit. The triglycerides level was determined by enzymatic colorimetric method described by Cole [17] using Dialab kit. The LDL-c level was deduced from the other lipids previously obtained using the formula described by Richmond [18].

Glutathion (GSH) was assayed according to the method of Sehirli et al. [19]. Malondialdehyde (MDA) was assayed according to the method of Draper and Hadley [20]. Catalase (CAT) was assayed according to the method of Luck [21]. SOD was assayed by the method of Sun et al. [22]. Nitric oxide (NO) was determined according to the method described by Sreejayan et Rao [23].

\section{Statistical analysis}

All results were expressed as mean \pm SEM (Standard Error of Mean). Statistical analyses were evaluated by one-way ANOVA followed by Turkey posttest using Graph Pad Prism Software Version 5.0. Statistical significance was accepted at $p<0.05$.

\section{Results}

Effect of the aqueous extract of $V$. paradoxa barks on relative body weight

Table 1 represents the variation in the body weight of animals during 2 weeks. It appears that the relative body weight of the animals in the diabetic control group decreased significantly the first $(p<0.05)$ and second $(p<0.01)$ weeks of the experiment, as compared to the normal control group.

Moreover, compared to the diabetic control group, no significant change in the relative body weight of the rats was recorded at the first week of treatment, with the exception of animals in the positive control group that increased significantly $(p<0.05)$. At the second week, glibenclamide and extract at the dose of $250 \mathrm{mg} / \mathrm{kg}$ resulted in a significant $(p<0.001)$ increase in the relative body weight. This increase was less important $(p<0.01)$ with doses of 125 and $500 \mathrm{mg} / \mathrm{kg}$.

\section{Effect of the aqueous extract of $V$. paradoxa on fasting} blood glucose and insulin levels

Table 2 shows the change in blood sugar and serum insulin levels in rats treated with $V$. paradoxa extract. This table shows that at time $t_{0}$, blood glucose of all animals significantly increased $(p<0.001)$, as compared to the normal control group.

Furthermore, blood glucose levels of all animals significantly decreased $(p<0.001)$ throughout the experiment as compared to the diabetic control group. The serum insulin level of animals in the diabetic control group significantly decreased $(p<0.001)$, as compared to the normal control group. However, there is a significant increase in serum insulin levels in animals treated with glibenclamide $(p<0.001)$ and the extract at doses of $125(p<0.05), 250(p<0.001)$ and $500 \mathrm{mg} / \mathrm{kg}(p<0.001)$ as compared to the diabetic control group.

Table 1 Effect of Vitellaria paradoxa extract on the relative body weight in alloxan-induced diabetic rats

\begin{tabular}{llll}
\hline Groups & \multicolumn{3}{l}{ Body weight $(\mathrm{g})$} \\
\cline { 2 - 4 } & Week 0 & Week 1 & Week 2 \\
\hline Normal control & $158.0 \pm 4.3$ & $169.6 \pm 2.0$ & $174.2 \pm 2.7$ \\
Diabetic control & $159.4 \pm 6.5$ & $159.0 \pm 6.7^{*}$ & $156.0 \pm 3.8^{* * *}$ \\
Glibenclamide $2.5 \mathrm{mg} / \mathrm{kg}$ & $149.0 \pm 4.3$ & $160.4 \pm 7.8 \mathrm{a}$ & $172.8 \pm 5.0 \mathrm{c}$ \\
Extract $125 \mathrm{mg} / \mathrm{kg}$ & $164.0 \pm 8.3$ & $169.6 \pm 10.9$ & $176.4 \pm 9.0 \mathrm{~b}$ \\
Extract $250 \mathrm{mg} / \mathrm{kg}$ & $192.3 \pm 13.4$ & $249.0 \pm 3.1$ & $265.0 \pm 3.6 \mathrm{c}$ \\
Extract $500 \mathrm{mg} / \mathrm{kg}$ & $158.0 \pm 4.4$ & $166.4 \pm 6.8$ & $174.6 \pm 8.3 \mathrm{~b}$
\end{tabular}

Each value is expressed as mean \pm S.E.M. $(n=5) .{ }^{* *} p<0.01 ;{ }^{* * *} p<0.001$ significantly different when compared to the normal control group. ${ }^{a} p<0.05$; ${ }^{\mathrm{b}} p<0.01 ;{ }^{c} p<0.001$ significantly different when compared to the diabetic control group 
Table 2 Effect of Vitellaria paradoxa on fasting blood glucose and serum insulin levels in alloxan-induced diabetic rats

\begin{tabular}{|c|c|c|c|c|}
\hline \multirow[t]{2}{*}{ Group } & \multicolumn{3}{|c|}{ Blood glucose level (mg/gL) } & \multirow{2}{*}{$\begin{array}{l}\text { Insulin }(\mu \mathrm{U} / \mathrm{mL} \\
\text { Day } 14\end{array}$} \\
\hline & Day 0 & Day 7 & Day 14 & \\
\hline Normal control & $80.4 \pm 2.2$ & $81.6 \pm 7.5$ & $83.4 \pm 7.9$ & $16.2 \pm 1.0$ \\
\hline Diabetic control & $173.0 \pm 2.1^{* * *}$ & $173.0 \pm 4.7^{* * *}$ & $174.4 \pm 4.4^{* * *}$ & $6.1 \pm 0.5^{* * *}$ \\
\hline Glibenclamide 2.5 mg/kg & $153.8 \pm 3.7^{* * *}$ & $99.0 \pm 7.8 \mathrm{c}$ & $94.2 \pm 7.8 \mathrm{c}$ & $15.3 \pm 1.1 c$ \\
\hline Extract $125 \mathrm{mg} / \mathrm{kg}$ & $162.2 \pm 11.9^{* * *}$ & $139.2 \pm 4.1^{* * * b}$ & $114.8 \pm 9.9^{* *} \mathrm{C}$ & $10.5 \pm 0.7^{* * a}$ \\
\hline Extract $250 \mathrm{mg} / \mathrm{kg}$ & $172.4 \pm 8.2^{* * *}$ & $111.0 \pm 7.7^{*} \mathrm{C}$ & $107.6 \pm 7.2^{*} \mathrm{C}$ & $13.2 \pm 0.9 c$ \\
\hline Extract $500 \mathrm{mg} / \mathrm{kg}$ & $165.2 \pm 4.7^{* * *}$ & $104.0 \pm 7.6 c$ & $92.6 \pm 8.2 c$ & $14.9 \pm 0.8 c$ \\
\hline
\end{tabular}

Each value is expressed as mean \pm S.E.M. $(n=5) .{ }^{*} p<0.05 ;{ }^{* *} p<0.01$; ${ }^{* * *} p<0.001$ significantly different when compared to the normal control group. ${ }^{a} p<0.05$; ${ }^{\mathrm{b}} p<0.01 ;{ }^{p} \mathrm{p}<0.001$ significantly different when compared to the diabetic control group

Effect of the aqueous extract of $V$. paradoxa on hepatic glycogen content and some liver enzymes activities

Table 3 shows the effect of $V$. paradoxa extract on hepatic glycogen level and the activity of certain liver enzymes. In the diabetic control group, there was a significant decrease $(p<0.001)$ in glycogen levels and glucokinase activity, and a significant $(p<0.001)$ increase in glucose-6-phosphatase activity $(p<0.01)$ and fructose-1, 6 -biphosphatase $(p<0.001)$, compared with the normal control group.

A significant increase in hepatic glycogen was observed with glibenclamide $(p<0.001)$ and the extract at doses of $250(p<0.01)$ and $500 \mathrm{mg} / \mathrm{kg}(p<0.01)$ as compared to diabetic control. Similarly, the activity of the glucokinase significantly increased in animals treated with glibenclamide $(p<0.001)$ and doses of $125(p<0.01), 250$ $(p<0.001)$ and $500 \mathrm{mg} / \mathrm{kg}(p<0.001)$ of extract. Standard product and extract $(250$ and $500 \mathrm{mg} / \mathrm{kg}$ ) resulted in a significant decrease $(p<0.05)$ in the activity of the glucose6-phosphatase. However, glibenclamide and extract caused a significant decrease $(p<0.001 ; p<0.01)$ in fructose-1,6-biphosphatase activity.

\section{Effect of the aqueous extract of $V$. paradoxa on lipid parameters}

Table 4 shows the effect of the aqueous extract of $V$. paradoxa barks on the lipid profile of the rats. There was a significant $(p<0.05)$ increase in total cholesterol, triglycerides and LDL-c level in the serum of animals of the diabetic control group, compared to the normal control group.

Moreover, compared to the diabetic control group, the triglycerides level significantly decreased in the animals treated with glibenclamide $(p<0.01)$ and extract at doses of $125(p<0.05), 250(p<0.05)$ and $500 \mathrm{mg} / \mathrm{kg}$ $(p<0.01)$. Likewise, a significant decrease $(p<0.01)$ in total cholesterol was observed exclusively in the animals treated at the dose of $500 \mathrm{mg} / \mathrm{kg}$ of extract. In addition, there is a significant decrease in LDL-c in animals treated with glibenclamide $(p<0.01)$ and doses of 125 $(p<0.01), 250(p<0.05)$ and $500 \mathrm{mg} / \mathrm{kg}(p<0.001)$ of extract. However, no significant variation in serum HDL-c was noted in the animals treated with the different doses of extract.

\section{Effect of the aqueous extract of $V$. paradoxa on some antioxidant parameters}

The effect of the aqueous extract of $V$. paradoxa on the level of nitric oxide, malondialdehyde and the activity of antioxidant enzymes is shown in Table 5. There was a significant decrease in the activity of catalase $(p<0.001)$, superoxide dismutase $(p<0.01)$ and glutathione $(p<0.01)$ in diabetic control group rats as compared to the normal control group. In contrast, a significant $(p<0.01)$ increase in malondialdehyde and nitric oxide level was observed in the liver of diabetic control group animals.

Table 3 Effect of Vitellaria paradoxa on glycogen content and some hepatic enzymes activities in alloxan-induced diabetic rats

\begin{tabular}{|c|c|c|c|c|}
\hline Groups & $\begin{array}{l}\text { Glycogen } \\
\text { (mg/g tissue) }\end{array}$ & $\begin{array}{l}\text { Fructose-1,6- } \\
\text { biphosphatase } \\
\text { (U/g protein) }\end{array}$ & $\begin{array}{l}\text { Glucose-6-phosphatase } \\
\text { (U/g protein) }\end{array}$ & $\begin{array}{l}\text { Glucokinase } \\
\text { (U/g protein) }\end{array}$ \\
\hline Normal control & $19.9 \pm 2.2$ & $154.7 \pm 3.9$ & $3.4 \pm 0.3$ & $0.34 \pm 0.01$ \\
\hline Diabetic control & $9.6 \pm 1.2^{* * *}$ & $197.2 \pm 4.2^{* * *}$ & $6.0 \pm 0.6^{* *}$ & $0.20 \pm 0.01^{* * *}$ \\
\hline Glibenclamide 2.5 mg/kg & $18.8 \pm 1.1 \mathrm{C}$ & $163.1 \pm 3.4 \mathrm{c}$ & $4.7 \pm 0.4 a$ & $0.31 \pm 0.01 c$ \\
\hline Extract $125 \mathrm{mg} / \mathrm{kg}$ & $14.4 \pm 1.0^{*}$ & $170.8 \pm 6.8 b$ & $5.3 \pm 0.3$ & $0.27 \pm 0.03 b$ \\
\hline Extract $250 \mathrm{mg} / \mathrm{kg}$ & $16.9 \pm 1.0 b$ & $167.5 \pm 4.6 b$ & $4.8 \pm 0.6 a$ & $0.34 \pm 0.02 c$ \\
\hline Extract 500 mg/kg & $16.8 \pm 0.6 b$ & $168.1 \pm 4.1 b$ & $4.1 \pm 0.3 a$ & $0.32 \pm 0.02 c$ \\
\hline
\end{tabular}

Each value is expressed as mean \pm S.E.M. $(n=5)$. ${ }^{*} p<0.05 ;{ }^{* *} p<0.01 ;{ }^{* * *} p<0.001$ significantly different when compared to the normal control group. ${ }^{a} p<0.05$;

${ }^{\mathrm{b}} p<0.01 ;{ }^{c} p<0.001$ significantly different when compared to the diabetic control group 
Table 4 Effect of Vitellaria paradoxa on lipid parameters in alloxan-induced diabetes in rats

\begin{tabular}{lllll}
\hline & $\begin{array}{l}\text { Total cholesterol } \\
(\mathrm{mg} / \mathrm{dL})\end{array}$ & $\begin{array}{l}\text { Triglycerides } \\
(\mathrm{mg} / \mathrm{dL})\end{array}$ & $\begin{array}{l}\mathrm{HDL}-\mathrm{c} \\
(\mathrm{mg} / \mathrm{dL})\end{array}$ & $\begin{array}{l}\mathrm{LDL}-\mathrm{c} \\
(\mathrm{mg} / \mathrm{dL})\end{array}$ \\
\hline Normal control & $34.1 \pm 2.1$ & $24.4 \pm 2.1$ & $12.1 \pm 2.6$ & $17.1 \pm 1.3$ \\
Diabetic control & $44.5 \pm 1.2^{*}$ & $34.6 \pm 1.3^{*}$ & $10.7 \pm 1.3$ & $26.9 \pm 1.6^{*}$ \\
Glibenclamide $2.5 \mathrm{mg} / \mathrm{kg}$ & $42.9 \pm 3.4$ & $20.2 \pm 2.2 \mathrm{~b}$ & $23.4 \pm 3.1^{*} \mathrm{a}$ & $15.4 \pm 0.8 \mathrm{~b}$ \\
Extract $125 \mathrm{mg} / \mathrm{kg}$ & $35.3 \pm 1.7$ & $23.6 \pm 2.6 \mathrm{a}$ & $14.3 \pm 2.2$ & $16.3 \pm 2.4 \mathrm{~b}$ \\
Extract $250 \mathrm{mg} / \mathrm{kg}$ & $39.2 \pm 1.1$ & $22.7 \pm 3.8 \mathrm{a}$ & $18.1 \pm 2.3$ & $16.6 \pm 2.8 \mathrm{a}$ \\
Extract $500 \mathrm{mg} / \mathrm{kg}$ & $30.1 \pm 2.6 \mathrm{~b}$ & $20.9 \pm 1.7 \mathrm{~b}$ & $13.3 \pm 1.1$ & $13.4 \pm 1.9 \mathrm{c}$ \\
\hline
\end{tabular}

Each value is expressed as mean \pm S.E.M. $(\mathrm{n}=5) .{ }^{*} p<0.05$ significantly different when compared to the normal control group. ${ }^{\mathrm{a}} p<0.05$; ${ }^{\mathrm{b}} p<0.01 ;{ }^{\mathrm{C}} p<0.001$ significantly different when compared to the diabetic control group

There was a significant increase in the level of nitric oxide in the animals treated with glibenclamide $(p<0.05)$ and doses of $250(p<0.05)$ and $500 \mathrm{mg} / \mathrm{kg}$ $(p<0.01)$ of extract as compared to animals in the diabetic control group. In contrast, a significant $(p<0.01)$ increase in malondialdehyde level was observed in the animals receiving the different treatments. Similarly, a significant increase in catalase activity was noted in rats given glibenclamide $(p<0.01)$ and doses of 125 $(p<0.05), 250(p<0.01)$ and $500 \mathrm{mg} / \mathrm{kg}(p<0.001)$ of extract. The activity of the superoxide dismutase significantly $(p<0.05 ; p<0.01)$ increased with reference product and the dose of $500 \mathrm{mg} / \mathrm{kg}$ of extract. Extract at doses of 250 and $500 \mathrm{mg} / \mathrm{kg}$ resulted in a significant increase $(p<0.05 ; p<0.01)$ in glutathione level.

\section{Discussion}

This study was conducted to investigate the antidiabetic and antioxidant effects of Vitellaria paradoxa barks in alloxan-induced diabetic rats. Alloxan monohydrate induces diabetes through its ability to destroy the $\beta$-cells of islets of Langerhans of the pancreas resulting in a decrease in endogenous insulin release, which affect the utilization of glucose by the tissues [24, 25]. Sulfonylureas drugs (glibenclamide for example) are known to lower the blood glucose level by stimulating $\beta$ cells to release insulin [26]. Previous phytochemical studies carried out on aqueous and methanol extracts of $V$. paradoxa bark have revealed the presence of several classes of chemical compounds (glycosides, saponins, phenols, alkaloids and flavonoids) responsible for the hypoglycaemic, lipid-lowering and antioxidant effects [27].

One of the main characteristics of type 1 diabetes is severe loss of body weight, probably due to muscle atrophy [28]. In the present study, the decrease in body weight observed in the diabetic control group is due to the hydrolysis of protein and lipid reserves in muscle tissue to produce energy, because of the inability of these tissues to metabolize blood glucose [25]. In contrast, the extract resulted in a significant increase in the relative body weight of the rats, indicating its effect on the control of muscle atrophy [29].

The extract of $V$. paradoxa resulted in a significant decrease in blood glucose levels and an increase in the serum insulin level of diabetic subjects. These results are attributable to the chemical compounds (flavonoids, phenols and glycosides) present in the extract that have the capacity to mimic the action of insulin or to stimulate its secretion by the $\beta$-cells of the islets of Langerhans $[30,31]$. The other possible mechanisms of the extract would be the regeneration of $\beta$ cells of the islets of Langerhans, the transport of blood glucose in peripheral tissue, the stimulation of glucose uptake by

Table 5 Effect of Vitellaria. paradoxa on antioxydant parameters

\begin{tabular}{llllll}
\hline Group & $\begin{array}{l}\mathrm{NO} \\
(\mu \mathrm{M})\end{array}$ & $\begin{array}{l}\mathrm{MDA} \\
(\mu \mathrm{M})\end{array}$ & $\begin{array}{l}\text { CAT } \\
(\mu \mathrm{mol} / \mathrm{min} / \mathrm{mg} \text { of protein })\end{array}$ & $\begin{array}{l}\text { SOD } \\
(\mathrm{U} / \mathrm{mg} \text { of protein) }\end{array}$ & $\begin{array}{l}\mathrm{GSH} \\
(\mu \mathrm{M})\end{array}$ \\
\hline Normal control & $49.7 \pm 2.1$ & $4.3 \pm 0.3$ & $78.9 \pm 3.5$ & $13.4 \pm 0.8$ & $480.0 \pm 43.1$ \\
Diabetic control & $82.2 \pm 5.8^{* *}$ & $7.3 \pm 0.3^{* *}$ & $49.2 \pm 3.5^{* * *}$ & $8.2 \pm 0.7^{* *}$ & $328.8 \pm 20.8^{* *}$ \\
Glibenclamide $2.5 \mathrm{mg} / \mathrm{kg}$ & $55.1 \pm 5.9 \mathrm{a}$ & $5.6 \pm 0.3 \mathrm{a}$ & $72.7 \pm 4.6 \mathrm{~b}$ & $12.7 \pm 1.5 \mathrm{a}$ & $443.3 \pm 19.5$ \\
Extract $125 \mathrm{mg} / \mathrm{kg}$ & $64.6 \pm 6.9$ & $5.9 \pm 0.4$ & $67.2 \pm 5.3 \mathrm{a}$ & $9.9 \pm 0.6$ & $440.2 \pm 17.3$ \\
Extract $250 \mathrm{mg} / \mathrm{kg}$ & $57.5 \pm 5.4 \mathrm{a}$ & $5.6 \pm 0.5 \mathrm{a}$ & $71.4 \pm 3.7 \mathrm{~b}$ & $11.2 \pm 0.8$ & $454.2 \pm 34.3 \mathrm{a}$ \\
Extract $500 \mathrm{mg} / \mathrm{kg}$ & $52.0 \pm 5.0 \mathrm{~b}$ & $5.5 \pm 0.4 \mathrm{a}$ & $76.7 \pm 3.4 \mathrm{c}$ & $13.9 \pm 1.0 \mathrm{~b}$ & $469.7 \pm 13.5 \mathrm{~b}$ \\
\hline
\end{tabular}

Each value is expressed as mean \pm S.E.M. $(\mathrm{n}=5) .{ }^{*} p<0.05 ;{ }^{* *} p<0.01 ;{ }^{* * *} p<0.001$ significantly different when compared to the normal control group. ${ }^{\text {a }} p<0.05$; ${ }^{\mathrm{b}} p<0.01 ;{ }^{c} p<0.001$ significantly different when compared to the diabetic control group 
peripheral tissues, the inhibition of endogenous glucose production or the activation of gluconeogenesis in the liver and muscles [32].

Glycogen is the reserve form of glucose in the liver and muscles during a reaction called glycogenogenesis. The transformation of glucose into glycogen is based on the existence of insulin; insulin stimulates glycogen synthesis by inhibition of glycogen phosphorylase [33]. Hepatic glucose storage in the glycogen form is greatly reduced in diabetic patients because of insulin deficiency [34]. Glibenclamide and $V$. paradoxa resulted in increased glycogen level in the liver of diabetic animals. This increase is due to the increase in insulin secretion [35] as observed in this study.

Glucokinase is an enzyme synthesized in the liver and responsible for the conversion of cytoplasmic glucose to glucose 6-phosphate, the first step of the conversion of glucose. The decrease in glucokinase activity causes the accumulation of blood glucose, and therefore hyperglycemia. In diabetic patients, insulin deficiency causes a disorder of carbohydrate metabolism due to decreased activity of various enzymes including glucokinase [36]. In the present study, glucokinase activity decreased significantly in animals in the diabetic control group, which is due to insulin deficiency. Administration of the extract and glibenclamide increased the glucokinase activity. This effect is due to the increase in insulin secretion, which in turn potentiates the activity of glucokinase, thus increasing the utilization of glucose and consequently decreasing the blood sugar level.

Glucose-6-phosphatase and fructose-1,6-bisphosphatase are the regulatory enzymes for gluconeogenesis. Insulin decreases gluconeogenesis by decreasing the activities of certain enzymes such as glucose-6phosphatase, fructose-1,6-bisphosphatase, phosphoenolpyruvate carboxykinase and pyruvate carboxylase [37]. Glucose-6-phosphatase is one of the enzymes in liver metabolism of glucose that catalyzes the final stage of glycogenolysis and gluconeogenesis in which glucose-6phosphate is hydrolyzed to glucose and phosphate [38]. Fructose-1,6-biphosphatase catalyzes one of the irreversible stages of gluconeogenesis [39]. The increased activity of these enzymes in the liver of diabetic subjects may be due to insufficient insulin [40]. The decrease in activity of these enzymes after the administration of the extract may be due to an increase in insulin secretion which is responsible for the repression of the key enzymes of gluconeogenesis.

Diabetes is associated with hyperlipidemia, which is characterized by an abnormal increase in cholesterol, triglycerides and lipoproteins. The abnormal rise in serum lipid levels in animals in the diabetic control group is mainly due to an increased mobilization of free fatty acids and peripheral fat deposits, since insulin has an anti-lipolytic action by inhibiting hormone-sensitive lipase [41]. The administration of the different doses of $V$. paradoxa extract would have improved the lipid profile of diabetic subjects either by mimicking the action of insulin or stimulating its biosynthesis. As a result, increased secretion of insulin stimulates fatty acid biosynthesis and incorporation into triglycerides of the liver and adipose tissue [31, 42]. The extract also slowed down the rate of diffusion through the intestinal mucosa reducing the absorption of cholesterol and triglycerides [43]. In addition, some authors have reported that secondary metabolites such as saponins, flavonoids and phenolic compounds have lipid-lowering activity [44]. The hypolipidemia observed would be related to the combined effect of these classes of chemical compounds present in the extract.

The strong presence of oxidative stress in diabetic subjects led us to evaluate the antioxidant properties of the aqueous extract of $V$. paradoxa bark. Measurement of MDA (final product of the lipid peroxidation) will reflect the degree of oxidative stress [45]. Indeed, the reduction of MDA is explained by the decrease in lipid peroxidation induced by increased production of antioxidant enzymes. In the present work, the extract (250 and 500 $\mathrm{mg} / \mathrm{kg}$ ) resulted in a decrease in the MDA level in diabetic subjects. The extract has the ability to block lipid peroxidation and therefore strengthen the antioxidant defense system. Because, induced hyperlipidemia leads to increased production of oxygen free radicals, thus causing lipid peroxidation [46].

Superoxide dismutase (SOD) is an enzyme that has a great effect on the biological defense mechanism by disproportionation of endogenous cytotoxic superoxide radicals into hydrogen peroxide $\left(\mathrm{H}_{2} \mathrm{O}_{2}\right)$ [47]. In this study, the activity of SOD decreased in diabetic control lot rats. On the other hand, the reference product and the dose of $500 \mathrm{mg} / \mathrm{kg}$ of extract caused an increase in hepatic SOD activity. V. paradoxa extract therefore has a significant effect on the oxidative defense mechanism of the body.

Catalase (CAT) is a tetrameric enzyme that efficiently converts $\mathrm{H}_{2} \mathrm{O}_{2}$ into oxygen and water. In contrast to glutathione, the affinity of the catalase for hydrogen peroxide is increased only when $\mathrm{H}_{2} \mathrm{O}_{2}$ levels are high [48]. Found extensively in organism that live in the presence of oxygen, CAT protects the cell from oxidative damage by reactive oxygen species (ROS) [49]. In the present study, the increase in catalase activity observed with $V$. paradoxa extract would therefore reflect a decrease in ROS level in the cell.

Glutathione (GSH) acts as an intra and extracellular antioxidant by participating in many biological processes. It reduces hydrogen peroxide, thereby lowering the lipid peroxidation levels [50]. In addition, GSH plays 
a fundamental role in cell defense against free oxygen radicals and other oxidative species [51]. In this work, hepatic GSH levels increased at all extract levels. This increase would reflect the strong potential of the extract in the defense of the cell against free radicals and reactive oxygen species.

Nitric oxide (NO) is a key metabolic and vascular regulator. Its production is stimulated by insulin. It is a diffuse free radical that plays several roles as an effector molecule in various biological systems (neuronal messenger, vasodilatation, antimicrobial and antitumor activities) [52]. NO is involved in diseases such as cancer and inflammation [53]. In the present study, the increase in the level of NO in the liver of diabetic animals group may be due to an insulin deficiency in the body, and consequently to hyperglycemia. Indeed, an increase in glucose concentration induces a rise in the level of intracellular diacylglycerol that activates protein kinase C, which has been shown to activate nitric oxide synthetase. On the other hand, the decrease in the hepatic NO level after the administration of the extract would be due to the insulin-mimetic and insulin-secretagogue effects of the extract. Moreover, it is proven that phenols and flavonoids are known as substances having an antioxidant activity. However, some plant extracts have been shown to contain antioxidant molecules that lower blood sugar by capturing free radicals to isolate their single electrons and transform them into stable molecules or ions [54]. This could again represent a possible mechanism of action of $V$. paradoxa on hypoglycaemia and antioxidant defense of the body.

\section{Conclusion}

The aqueous extract of $V$. paradoxa barks possess the hypoglycaemic, hypolipidemic and antioxidant effects, thus justifying the validity of the traditional use of this extract as a treatment for diabetes and some of its complications.

\section{Abbreviations \\ ANOVA: Analysis of variance; CAT: Catalase; ELISA: Enzyme-linked immunosorbent assay; GSH: Glutathione; HDL-c: High density lipoprotein cholesterol; LDLc: Low density lipoprotein cholesterol; \\ MDA: Malondialdehyde; NHC: National Herbarium of Cameroon; NO: Nitric oxide; OS: Oxidative stress; SEM: Standard error of the mean; \\ SOD: Superoxide dismutase}

\section{Acknowledgments}

The authors are grateful to the Pastor Center of Garoua (Cameroon) and Laboratory of Life and Earth Sciences of the University of Maroua

(Cameroon) for providing the facility to carryout the research.

\section{Authors' contributions}

NTL and CMMT proposed the plant material, harvested and prepared the crude extract. DM, NTL and CMMT conducted the different tests in laboratory. DM and OKG analyzed the data and drafted the article. AK corrected the final manuscript. All authors approved the final version of the manuscript.
Funding

None.

\section{Availability of data and materials}

All data generated or analysed during the present work are included in this article. Animals were obtained from the animal house of the Laboratory of Animal Physiology and Phytopharmacology (Faculty of Sciences, University of Dschang, Cameroon).

\section{Ethics approval and consent to participate}

All animal experiments were handled according to the Cameroon National Ethics Committee (Ref. N FWIRB 00001954) and all experiments have been examined and approved.

\section{Consent for publication}

Not applicable.

\section{Competing interests}

The authors declare no conflict of interest.

\section{Author details}

'Department of Life and Earth Sciences, Higher Teachers' Training College, University of Maroua, Maroua, Cameroon. ²Department of Animal Biology, Faculty of Sciences, University of Dschang, Dschang, Cameroon.

Received: 10 August 2019 Accepted: 11 December 2019

Published online: 19 December 2019

References

1. ADA. Diagnosis and classificationof diabetes mellitus. Diabetes Care. 2010; 33(1):62-9.

2. Sanofi. Diabetes: a global epidemic, 2013.

3. IFD. Diabetes Atlas, 6th edition, 2013.

4. WHO. Alert on the rise in the number of diabetics in the world, 2016.

5. Guerreiro L. Diabetes synthesis, nursing care for people with diabetes, 2007.

6. Guler E, Manav E, Ugurlu E. Medicinal plants used by traditional healers in Bozuyuk (Bilecik-Turkey). J Ethnopharmacol. 2015;17:339-47.

7. WHO. Expert committee on diabetes mellitus. Technical Report Series 646. Geneva, Switzerland: World Health Organization; 1980.

8. Kumar S, Kumar V, Prakash O. Antidiabetic and anti-hyperlipidemic effects of Dillenia indica (L.) leaves extract. Braz J Pharm Sci. 2011;47(2):1-6.

9. Rabiat U, Hamzah C. Evans, Egwim Y, Adamu, Kabiru, Mary, Muazu B. phytochemical and in vitro antioxidant properties of the methanolic extract of fruits of Blighia sapida, Vitellaria paradoxa and Vitex doniana. Oxid Antioxid Med Sci. 2013;2(3):217-23.

10. Coulibaly FA, et al. Evaluation of the antidiabetic activity of the extracts of Vitellaria paradoxa in Oryctolagus cuniculus rabbit (lagomorph). Int J Sci Technol Educ Res. 2014:24(3):1673-82.

11. Van Der Vies J. Two methods for the determination of glycogen in liver. Biochem J. 1954:57(3):410-6.

12. Brandstrup N, Kir JE, Bruni C. Determination of hexokinase in tissues. J Gerontol. 1957:12:166-71.

13. Koida H, Oda T. Pathological occurrence of glucose-6-phosphatase in liver disease. Clin Chim Acta. 1959;4:554-61.

14. Gancedo JM, Gancedo C. Fructose 1,6-bisphosphatase, phosphofructokinase and glucose 6-phosphate dehydrogenase from fermenting and nonfermenting yeasts. Arch Mikrobiol. 1971;76(2):132-8.

15. Trinder P. Quantitative in vitro determination of cholesterol in serum and plasma. Ann Clin Biochem. 1969:6:24-7.

16. Wiebe DA, Warnick GR. Measurement of high-density lipoprotein cholesterol. In: Rafai N, Warnick GR, Sunday MH, editors. Hand book of lipoprotein testing. Washington: AACC Press; 1997. p. 9-107.

17. Cole TG, Klotzsch SG, Mcnamara J. Measurement of triglyceride concentration. In: Rifai N, Warnick GR, Dominissak MH, editors. Handbook of Lipoprotein testing. Washington: AACC Press; 1997. p. 26-115.

18. Richmond W. Preparation and properties of cholesterol oxidase from Nucurdia sp. and its application to enzymatic assay of total cholesterol in serum. Clin Chem. 1973:19:1350-6.

19. Sehirli O, Tozan A, Omurtag GZ, Cetine S, Contuk G, Gedik N, Sener G. Protective effets of resveratol against naphtylene-induced oxidative stress in mice. Ecotoxicol Environ Saf. 71(1):301-8. 
20. Draper $\mathrm{HH}$, Hadley M. Malondialdehyde determination as index of lipid peroxidation. Methods Enzymol. 1990;186:21-431.

21. Luck H. Catalase. In: Bergmeyer HU, editor. Methods of enzymatic analysis. New York: Academic Press; 1971.

22. Sun Y, Oberley LW, Li Y. A simple method for clinical assay of superoxide dismutase. Clin Chem. 1988;34(3):497-500.

23. Sreejayan N, Rao M. Nitric oxide scavenging by curcuminoids. J Pharm Pharmacol. 1997:49(1):105-7.

24. Mooradian AD. Dyslipidemia in type 2 diabetes mellitus. Nat Clin Pract Endocrinol Metab. 2009:5(3):150-9.

25. Pari L, Maheswari J. Hypoglycaemic effect of Musa sapientum L. in alloxaninduced diabetic rats. J Ethnopharmacol. 1999;68(1-3):321-5.

26. El-Mahmood AM, Doughari JH, Ladan N. Antimicrobial screening of stem bark extracts of Vitellaria paradoxa against some enteric pathogenic microorganisms. Afr J Pharm Pharmacol. 2(5):89-94.

27. Oliveira ACP, Endringer DC, Amorim LAS, Dasgraca M, Brandao MGL, Coelho MM. Effect of extracts and fractions of Baccharistrimera and Syzygiumcumini on glycemia of diabetic and non-diabetic mice. J Ethnopharmacol. 2005; 102(3):465-9.

28. Farida A, Shoukry M. The lipid lowering effect of an anti-diabetic plant extract. Acta Diabetol Lat. 1988;25(1):1-5.

29. Whitton PD, Hems DA. Glycogen synthesis in perfused liver of streptozotocin diabetic rats. Biochem J. 1975;21(2):150-3.

30. Tanko Y, Yerima M, Mahdi MA, Yaro AH, Musa KY, Mohammed A. Hypoglycemic activity of methanolic stem bark of Adansonnia digitata extract on blood glucose levels of STZ-induced Wistar rats. Int J Appl Res Nat Prod. 2008;1(2):32-6.

31. Khurshid Alam AHM, Sharmin R, Maruf I, Hasibul Hasan J, Mohiuddin A, Golam M. Antidiabetic and hepatoprotective activities of Bombax ceiba young roots in alloxan-induced diabetic mice. J Nutr Health Food Sci. 2018;6(5):1-7.

32. Burcelain R, Eddouks M, Maury J, Kande J, Assan R, Girard J. Excessive glucose production rather than insulin resistance accounts for hypoglycaemia in recent onset diabetic rats. Diabetologia. 1995;38:283-90.

33. Bhandari U, Chaudhari HS, Khanna G, Najmi AK. Antidiabetic effects of Embelia ribes extract in high fat diet and low dose streptozotocin-induced type 2 diabetic rats. Front Life Sci. 2013;7(3-4):186-96.

34. Bollen M, Keppens S, Stalmans W. Specific features of glycogen metabolism in the liver. Biochem J. 1998:336(1):19-31.

35. Arokiyaraj S, Balamurugan R, Augustian P. Antihyperglycemic effect of Hypericum perforatum ethyl acetate extract on streptozotocin-induced diabetic rats. Asian Pac J Trop Biomed. 2011;1(5):386-90.

36. Goyal RK, Bhullar SS, Singh R. Comparative sensitivity to inorganic phosphate of sucrose to starch conversion in sorghum and wheat grains raised through culture. Plant Physiol Biochem. 1999;28:755.

37. Arati G, Sachdanandam S. Therapeutic effect of Semecarpus and Cardium Linn, nut milk extract on carbohydrate metabolizing and mitochondrial TCA cycle and respiratory chain enzymes in mammar carcinoma rats. J Pharm Pharmacol. 2003;55(9):1283-90

38. Zhou C, Ge X, Liu B, Xie J, Chen R, Ren M. Effect of high dietary carbohydrate on the growth performance, blood chemistry, hepatic enzyme activities and growth hormone gene expression of Wuchang bream (Megalobrama amblycephala) at two temperatures. Asian Australas J Anim Sci. 2015;28(2):207.

39. Hassan HA, El-Agmy SM, Gaur RL, Fernando A, MHG R, Ouhtit A. In vivo evidence of hepato and reno-protective effects of garlic oil against sodium nitrite-induced oxidative stress. Int J Biol Sci. 2009;5(3):249-55.

40. Rajagopal K, Sasikala K. Antihyperglycaemic and antihyperlipidaemic effects of Nymphaea stellata in alloxan-induced diabetic rats. Singap Med J. 2008; 49(2):137-41.

41. Best CH, Taylor NB. Biological effects of insulin. In: Williams W, Wilkins, editors. Physiological basis of medical practice. London: Cambridge University Press; 1989.

42. Dall'Agnol R, Poser $G$. The use of complex polysaccharides in the management of metabolic diseases: the case of Solanum lycocarpum fruits. J Ethnopharmacol. 2000;7(1-2):337-41.

43. Hooper PCH, Kroon PA, Rimm EB, Cohn JS, Harvery I, Le Cornu KA, Ryder JJ, Hall WL, Cassidy A. Flavonoids, flavonoid-rich foods, and cardiovascular risk: a meta-analysis of randomized controlled trials. Am J Clin Nutr. 2008:88(1):38-50.

44. Limaye PV, Raghuram N, Sivakami S. Oxidative stress and gene ion of antioxidant enzymes in the renal cortex of streptozotocin induced diabetic rats. Mol Cell Biol. 2003;243(1-2):147-52.
45. Oh PS, Lee SJ, Lim KT. Hypolipidemic and antioxydative effects of the plant glycoprotein (36 kDa) from Rhus verniciflua stokes fruit in triton Wr-1339 induced hyperlipidemic mice. Biosci Biotechnol Biochem. 2006;70(2):447-56.

46. Hassan HM. Biosynthesis and regulation of superoxide dismutases. Free Radic Biol Med. 1988:5(6):377-85.

47. Mates JM, Perez-Gomez C. Nunez de Castro I. Antioxidant enzymes and human diseases. Clin Chem. 1999;32(8):595-603.

48. Kappus H. Lipid peroxidation: mechanisms, analysis, enzymology and biological relevance. In: Sies H, editor. Oxidative stress. London: Academic Press; 1985

49. Chelikani P, Fita I, Loewen PC. Diversity of structure and properties among catalases. Cell Mol Life Sci. 2004;61(2):192-208.

50. Packer L, Tritschler HJ, Wessel K. Neuroprotection by the metabolic antioxidant alpha-lipoic acid. Free Radic Biol Med. 1997;22(1-2):359-78.

51. Arivazhagan S, Balasenthil S, Nagini S. Garlic and neem leaf extracts enhance hepatic glutathione and glutathione dependent enzymes during $\mathrm{N}$-methyl-Nnitrosoguanidine (MNNG)-induced gastric carcinogenesis. Phytother Res. 2000;14(4):291-3.

52. Hagerman AE, Riedl KM, Jones GA, Sovik KN, Ritchard NT, Hartzfeld PW. High molecular weight plant polyphenolics (tannins) as biological antioxidants. J Agric Food Chem. 1998;46(68):1887-92.

53. Miller MJ, Sadowska K, Chotinaruemol S, Kakkisand JL, Clark DA. Amelioration of chronic iletis by nitric oxide synthase inhibition. J Pharmacol Exp Ther. 1993;264(1):11-6.

54. Qiong L, Yizhong C, Jun Y, Mei S, Harold C. Hypoglycemic and Hypolipidemic effects and antioxidant activity of fruit extract of Lycium barbarum. Life Sci. 2004;761(3):37-149.

\section{Submit your manuscript to a SpringerOpen ${ }^{\circ}$ journal and benefit from:}

- Convenient online submission

- Rigorous peer review

- Open access: articles freely available online

- High visibility within the field

- Retaining the copyright to your article

Submit your next manuscript at $>$ springeropen.com 